\title{
Synthesis of Microfinance and Technical Efficiency: Implications for Poverty Reduction in Ghana
}

\author{
Samuel Erasmus Alnaa ${ }^{1, *} \&$ Ferdinand Ahiakpor ${ }^{2}$ \\ ${ }^{1}$ Department of Accountancy, Bolgatanga Polytechnic, Bolgatanga, Ghana \\ ${ }^{2}$ Department of Economic and Econometrics, University of Johannesburg, South Africa \\ *Corresponding author: Department of Accountancy, Bolgatanga Polytechnic, Bolgatanga, \\ Ghana. Tel: 233-206-663-739. E-mail: sam.alnaa@gmail.com
}

Received: November 11, 2014 Accepted: February 11, 2015 Published: March 25, 2015

doi:10.5296/rae.v7i1.6599 URL: http://dx.doi.org/10.5296/rae.v7i1.6599

\begin{abstract}
This paper uses field survey data to assess the mechanism through which microfinance can reduce poverty among rural households in the Upper East Region of Ghana. Data was collected from 500 women engaged in agro processing of whom 250 were beneficiaries of microfinance. The results from the Ordinary Least Square estimation reveal that an increase in technical efficiency of microfinance beneficiary has a positive impact on poverty reduction. In this regard, microfinance institutions are edged to incorporate training and business advisory services as part of their service delivery so as to make their clients more technically efficient.
\end{abstract}

JEL Classification: C2, D130, D140, G00

Keywords: Microfinance, Poverty reduction, Synthesis; Technical Efficiency 


\section{Introduction}

The importance of microfinance in fostering poverty reduction in less developed countries cannot be overemphasized. However, empirical literature on the impact of microfinance on poverty reduction has been mixed. Despite the fact that empirical literature has been mixed, microfinance is considered as a tool to achieving the Millennium Development goals, especially in terms of poverty eradication (Dunford, 2006).

Microfinance is hailed by many as an important tool for poverty alleviation (Seibel, 2005; Litttlefield, Morduch \& Hashemi, 2003). Lensik and Hermes (2011) found in the study on impact of microfinance on poverty that household's access to microfinance may contribute to a long-lasting increase in income by means of increase households investments in income generating activities and possible diversification of resources, accumulation of resources which will smoothen household consumption, reduce the vulnerability of households due to illness, drought and crop failures, improve better education, health and housing. In addition, it would contribute to an improvement of the social and economic situation of women and have positive spill-over impact.

Islam, Bäckman and Sumelius (2011), empirically examined the technical, economic and allocative efficiency of agricultural microfinance borrowers and non-borrowers in rice farming in Bangladesh using data envelopment analysis of survey data obtained in 2009. They found the mean of technical, allocative, and economic efficiencies to be 72, 66 and 47 percent respectively which indicate existence of substantial gains in output as a result of the micro credit obtained. Also, Tariq and Mohd-Izhar (2010) applied the stochastic frontier approach for unbalanced panel of 40 microfinance institutions for the 2005-08 in India and found that mean efficiency level of microfinance institutions was quite low but it increases over the period.

Annim and Alnaa (2013) used treatment effect approach to estimate the impact of microfinance on poverty reduction in the Upper East Region of Ghana. The results of the study supported the hypothesis that microfinance has $0.12 \%$ poverty reducing effect. Premised on this, it was concluded that even in very poor areas microfinance was capable of reducing poverty.

In a related study, Goyal and Suhag (2003) using unbalanced panel data for three years from 1996-97 to 1998-99 which was collected from 200 wheat farmers spread over in each year forming 592 total observations. The study applied stochastic frontier production function for the wheat farmers. The frontier function involved inputs such as human labour, fertilizers, irrigation expenditure, seeds, land area and capital expenditure. The null hypothesis of absence of technical inefficiency effects was rejected. Farm specific technical efficiencies estimated were observed to be time varying. It indicated that, the mean technical efficiency was found to deteriorate through the years in wheat production. It declined from 0.9172 in first year to 0.9025 in third year. The mean technical efficiency indicated that the realized output could be increased by about 10 percent without any additional resources. More than two-third of total sample farmers had technical efficiency above 0.90 . 
Bhasin and Akpalu (2001) in a study of hairdressers, dressmakers and wood-processors in Cape Coast found the mean technical efficiency as $75.7 \%, 83.4 \%$ and $89.1 \%$ respectively. The study again found that hairdressers, dressmakers and wood-processors that had better access to credit were relatively more efficient than their counterparts who did not receive credit. Finally, Akpalu, Alnaa and Aglobitse (2011) used stochastic frontier approach to examine the impact of access to and found access to microfinance to increase efficiency by $11 \%$.

Despite the positive impact of microfinance on poverty reduction, critics of microfinance argue that credit is not appropriate for the core poor. This is because they are of the view that the loans will normally not be used by the poor for business purposes. They argue that for microfinance to serve the purpose of poverty reduction, it must be given to those who have identified an economic opportunity and can capitalize on it if they have access to a small amount of ready cash. But the core poor if given the credit will use it on their current consumption and still remain poor in the long run.

Also, it is argued that the extreme poor often decide not to participate in microfinance programs since they lack confidence or they value the loans to be too risky (Ciravegna, 2005). The poorest of the poor, the so-called core poor, are generally too risk averse to borrow for investment in the future. They will, therefore, benefit only to a very limited extent from microfinance schemes. In general, the core poor are often not accepted in group lending programmes by other group members because they are seen as a bad credit risk (Hulme \& Mosley, 1996; Marr, 2004). Aside groups excluding poor members, staff members of microfinance institutions may prefer excluding the core poor since lending to them is seen as extremely risky (Hulme \& Mosley, 1996). Finally, the way microfinance programmes are organized and set up may lead to the exclusion of the core poor. Examples for this exclusion are the requirement to save before a loan can be granted, the minimum amount of the loan that needs to be accepted and the requirement that a firm is registered before the loan can be granted (Kirkpatrick \& Maimbo, 2002; Mosley, 2001).

There has been a traditional argument that loans can temporarily enhance a household's productive human and physical capital and increase their productivity that lead to reduction in poverty. In addition, savings and credit services are also considered to increase household's risk-bearing potential, leading to the adoption of more risky but potentially more profitable income-generating activities. The profitability and mix of productive activities may change, leading to increased income that contributes to the virtuous production and investment cycle (Zeller, Schrieder, Von Braun, and Heidhues, 1997).

Dunn, (1996) observed that credit obtained through microfinance programme, provides additional resources to support the household's activities which help to increase their consumption levels as they use the credit to undertake productive activities that increase the income level during the period Also, Marguerite (2001) indicated that for the economically active poor of the developing world, there is strong demand for small scale commercial financial services and this help them to increase productivity, smooth income flows and consumption, enlarge and diversify their micro business and increase their incomes which has 
a positive impact of the life's through a drastic reduction in the rate of poverty.

There have been several empirical studies on the impact and sustainability of micro finance programme in reducing poverty in developing countries especially Ghana. However, there has not been any known empirical study in Ghana that examined impact, technical efficiency and the pathway(s) of microfinance to poverty reduction. The impression created in previous empirical studies on the subject is that microfinance could be a magic wand to poverty reduction. However, the study argues that, microfinance requires a combination of other ingredients to be able to reduce poverty. Therefore, the main contribution of this study is to fill the gap in the literature by determining impact, technical efficiency and the paths to poverty reduction. Finally, the findings of this study would provide policy makers in Ghana with an important tool that should inform policies. The rest of the paper is structured as follows: Section 2 presents the empirical model specification for the study. The data and data collection procedure is presented in section 3, while section 4 presents the results and discussion. Finally, section 5 presents the conclusion.

\section{Data and Data Collection}

The data used in this study were obtained from microfinance beneficiaries (treatment group) and non-beneficiaries (control group) in Upper East region of Ghana between June 2011 to August 2011. A total of 500 women engaged in agro-processing were interviewed.

\subsection{Sampling and sampling size}

In determining the sample size of this study, a multi-stage sampling was used. Firstly, five out of the nine districts in the region were selected at random. Secondly, four communities were selected from each of the selected districts, of which two were having microfinance clients engaged in agro-processing and the other two were non-clients but also engaged in agro-processing activities. This was done to give each community a fair representation.

Finally 20 communities were selected, and the optimal sample size used in the study was derived from the following equation:

$$
n=t^{2} * p(1-\mathrm{p}) / m^{2}
$$

Where $n$ is the desired sample size, $t=$ the standard normal deviation set at $1.96 p=$ estimated prevalence of poverty, $m=$ margin of error $(0.05)$. To address the problem of non-respondents and missing values, $2 \%$ of the desired sample size was added.

\subsection{The questionnaire}

To keep the questionnaire simple so that it could be filled in quickly, majority of the questions were made closed ended and few open ended. The questionnaire was divided into five parts as follows: Demographic information of the respondent, microfinance activities, wealth indicators, socio cultural factors and food stuff consumption. 


\subsection{Distribution of questionnaires}

The questionnaire was sent to a total of 250 microfinance clients and another 250 non-microfinance clients in the communities selected. All the questionnaires were administered by research assistants. It demands about twenty minutes of the respondent time. This meant that questionnaire were administered and collected during the same visit, ensuring a 100 per cent response rate.

\section{Empirical Model}

Following the work of Akpalu, Alnaa and Aglobitse (2011) and Annim and Alnaa (2013 the empirical model use for this study is specified as follows:

$$
\begin{aligned}
& \text { lacesprof }=\alpha_{0}+\alpha_{1} \text { hhppl }+\alpha_{2} \text { depend }+\alpha_{3} \text { oldsav }+\alpha_{4} \text { numacty }+\alpha_{5} \text { age }+\alpha_{6} \text { age } 2 \\
& \quad+\alpha_{7} \text { assets }+\alpha_{8} \text { kasena }+\alpha_{9} \text { bwest }+\alpha_{10} \text { labour }+\alpha_{11} \text { finputc }+\alpha_{12} \text { vinputc }+\alpha_{13} \text { eff }+u
\end{aligned}
$$

Where hhppl represent the number of people in household, depend ( number of dependents in household), oldsav ( initial savings), age (age of respondent), assets (value of assets) kasena (KasenaNankanaDistrict), bwest (Bawku West District), output (value added), labour (number of people engaged in the business), finputc (capital input), vinputc (direct materials), while $\mu$ is the error term.

\section{Results and Discussion}

The results and discussion on the estimated treatment effect model is presented in this section. This is preceded by a presentation of the descriptive statistics of the variables used for the empirical estimation.

Table 1. Descriptive Statistics of Variables

\begin{tabular}{lrrr}
\hline Variables & Observations & Mean & Standard Deviation \\
\hline KasenaNankana District (1/0) & 490 & 0.2 & 0.4 \\
Bawku west District (1/0) & 490 & 0.2 & 0.4 \\
Age in years & 490 & 39.52 & 11.55 \\
Dependants in household & 490 & 3.12 & 2.14 \\
Number of friends with loans & 490 & 3 & 4.5 \\
Household members with loans & 490 & 0.3 & 0.61 \\
Has received microfinance & 490 & 0.51 & 0.5 \\
institution loan(1/0) & & & \\
Direct materials & 438 & 204.89 & 731.77 \\
Fixed inputs & 385 & 195.55 & 596.75 \\
Number of people engaged & 490 & 1.64 & 1.23 \\
Output(value added) & 323 & 133.18 & 302.7 \\
\hline
\end{tabular}


Number of economic activities

Initial savings

Days in a production cycle

Needs permission to borrow $(1 / 0)$

A male controls her business $(1 / 0)$

Educational level:

No formal education(1/0)

Non-formal education( $1 / 0)$

Primary school(1/0)

JSS/Middle school(1/0)

SSS/Secondary school(1/0)

Post Secondary school $(1 / 0)$

Source: Household Survey data (2011)

Table 1 provides the description of the data used for the study. Access to microfinance is a dummy variable which takes the value 1 if the respondent has received a loan from microfinance institutions. The mean value of access to microfinance is 0.508 implying $51 \%$ of the respondents received loan(s) from an microfinance institutions. The district dummy variables for Kasena-Nankani and Bawku West Districts have a mean value of 0.20, suggesting about $20 \%$ of the respondents are from each of the two Districts. Both districts have very vibrant market centres with patronage from the neighbouring country, i.e., Burkina Faso. Therefore the two dummy variables control for the effect of these market centres. The mean age of the respondents is found to be approximately 40 years (with relatively low variance) indicating a larger proportion of the respondents are within the economically active age group. The mean number of dependents within the household is 3 .

The direct materials and fixed input shows the value in cedis of materials used in processing the final product. The number of people engaged is measured as the physical number of people engaged by the respondent in her economic activity, which includes the respondent herself while the output measured as the value added in cedis. The direct materials, fixed input and output are all valued at prices in Bolgatanga market. Need to seek permission from husband before borrowing is constructed as a binary variable. It takes the value 1 if the respondent must seek permission from her husband, household head or any male member in the household before she accesses a microfinance institution loan, and 0 if otherwise. The mean of need to seek permission first is given as 0.604 , implying that about $60 \%$ of the respondents had to seek permission from their husband or a male member of the household before accessing a loan from an microfinance institution. Either a male control her business is binary: it takes the value 1 if the respondent's husband or any male member of the household controls her (respondent's) business, and 0 if otherwise. Its mean value is 0.162 which indicates about $16 \%$ of the respondents had their business controlled by a male member of the household.

The need to seek permission before taking loan and male control over business measure decision making and control of resources in the household. Further, the level of education is a categorical variable measuring the highest educational level of the respondent. The mean of 
each level (category) of education shows the proportion (percentage) of the respondents in that category. Of this variable $43.4 \%$ have no formal education, $7.1 \%$ have non-formal education, 26.6\% have Primary school education, $15.4 \%$ have JSS/Middle school education, and $6.8 \%$ have secondary school education, while $0.083 \%$ has post secondary school education. The no formal education is used as the reference category.

Table 2. Treatment Effect Estimation of Impact of Access to Microfinance Dependent Variable: Log of Weekly Consumption Expenditure

\begin{tabular}{|c|c|c|c|}
\hline Variable & Coefficient & Std. error & P-Value \\
\hline KasenaNankana District (1/0) & $0.342 * * *$ & 0.070 & 0.000 \\
\hline Bawku west District $(1 / 0)$ & $0.548 * * *$ & 0.066 & 0.000 \\
\hline Age in years & $0.0477 * * *$ & 0.014 & 0.001 \\
\hline Age-squared & $-0.001 * * *$ & 0.0002 & 0.000 \\
\hline Dependants in household & $0.0294 * *$ & 0.0128 & 0.022 \\
\hline Number of people in household & -0.009 & 0.009 & 0.318 \\
\hline Number of borrowing sources & 0.004 & 0.067 & 0.957 \\
\hline Amount of profit & $0.001 * *$ & 0.001 & 0.025 \\
\hline No. of income generating activities & $0.048 * *$ & 0.0214 & 0.025 \\
\hline Initial savings & $0.0004 *$ & 0.000206 & 0.064 \\
\hline Value of physical assets & 0.000015 & 0.000028 & 0.593 \\
\hline $\begin{array}{l}\text { Has received microfinance institution } \\
\text { loan }(1 / 0)\end{array}$ & $0.397 * *$ & 0.093 & 0.000 \\
\hline Primary school(1/0) & $0.170 * * *$ & 0.064 & 0.008 \\
\hline JSS/Middle school(1/0) & $0.173 * *$ & 0.074 & 0.020 \\
\hline SSS/Secondary school(1/0) & -0.122 & 0.110 & 0.267 \\
\hline Post Secondary school(1/0) & 0.202 & 0.308 & 0.511 \\
\hline Constant & 1.395 & 0.295 & 0.183 \\
\hline Observations. & 437 & & \\
\hline $\operatorname{rho}(\rho)$ & $-0.298 * *$ & 0.120 & \\
\hline $\operatorname{sigma}(\sigma)$ & $0.496^{* * *}$ & 0.018 & \\
\hline $\operatorname{Lambda}(\lambda)$ & $-0.148 * *$ & 0.062 & \\
\hline Wald chi2(16) & $223.23 * * *$ & & \\
\hline Log likelihood & -518.74472 & & \\
\hline
\end{tabular}

Source: Annim and Alnaa, (2013): Wald test of indep. eqns. (rho =0): chi2(1) 4.39**

$$
* * * \mathrm{p}<0.01, * * \mathrm{p}<0.05, * \mathrm{p}<0.1
$$

The results from Table 2 indicate that the coefficient of access to microfinance is $(0.397)$ showing a positive relationship with weekly consumption expenditure. This indicates that beneficiaries of microfinance institutions loans spend, on the average 40 percent higher than non-beneficiaries of microfinance institutions loans in the Upper East Region of Ghana holding all other factors constant. This means that benefiting from microfinance institutions loans has the effect of increasing weekly consumption expenditure on basic needs on the average by 40 percent (Annim \& Alnaa, 2013). 


\section{Macrothink}

Table 3 shows the post estimation results of the treatment effect method. The study used consumption expenditure as a proxy for poverty reduction. It reveals that, an increase in consumption expenditure leads to poverty reduction. The results from Table 2 show the t-test of the significance of the mean difference of weekly consumption expenditure of beneficiaries and non-beneficiaries of microfinance institution loans estimated at the means contingent on all the variables that were significant in explaining weekly consumption expenditure. The mean weekly consumption expenditure for beneficiaries of microfinance institution loans is 3.055 while that of non-beneficiary is 2.952 .

The anti-log of these figures indicated that beneficiaries of microfinance institution loans spent about GHф21.22 per week on basic needs while non-beneficiaries spent GH $\not 19.14$ per week on basic needs. However, the difference between the mean weekly consumption expenditure for the two groups is $\mathrm{GH} \not 1.11$. The t-test of the null $\left(\mathrm{H}_{0}\right)$ that the difference in weekly consumption expenditure for the two groups was equal to zero, was rejected given the t-test value of 4.0701 . This indicated that beneficiaries spent GH $\notin 1.11$ more per week on basic needs than non-beneficiaries.

Table 3. Two-sample t-test with Unequal Variances for Weekly Consumption Expenditure

\begin{tabular}{lll}
\hline Variable & Mean & Std. Dev. \\
\hline Beneficiary expenditure (B) & 3.055 & 0.331 \\
Non beneficiary expenditure (N) & 2.952 & 0.409 \\
diff.(B-N) & 0.103 & 0.169
\end{tabular}

$\mathrm{H}_{0}$ : diff $=0$

Observation: 437

Source: Annim and Alnaa, (2013)

Using the non-beneficiaries consumption expenditure as a counterfactual outcome for the beneficiaries consumption expenditure therefore, it indicated that beneficiaries would have been spending GHф19.14 per week on basic needs if they had not benefited from the microfinance institution loans; instead spent GH\&21.22 per week on basic needs, that is GH $\not 1.11$ per week more. This suggested that MF had increased beneficiaries' consumption expenditure by GH $\notin 1.11$ per week on basic needs. By implication access to MF contributed to poverty reduction(Annim \& Alnaa, 2013). 


\section{Ml Macrothink}

The coefficient of Received microfinance institution loan is positive implying women who have accessed or received microfinance institutions loans are more efficient than their counterpart non-beneficiaries. On the average beneficiaries are $11 \%$ more efficient than non-beneficiaries. This could be so because those who borrow from microfinance institutions are also given training in business management and other related financial management. These trainings are supposed to enhance the skills of the MF beneficiaries. Secondly by virtue of the fact that these women took loans from microfinance institutions, they are compelled to work harder so as to make enough profits to repay the loans and the accompanying interest. These are motivations for the beneficiaries of microfinance to be more efficient than the non-beneficiaries (Akpalu, Alnaa \& Aglobitse, 2011).

\subsection{Synthesis of microfinance, technical efficiency and consumption expenditure}

This section provides a synthesis of microfinance, technical efficiency and consumption expenditure with the aid of Figure 1. It draws insights from the results on Tables 2, 3 and 4.

Table 4. Determinants of technical efficiency among microenterprises in UER of Ghana

\begin{tabular}{lcl}
\hline Variables & Coefficients & Standard Errors \\
\hline Received microfinance institution $(1 / 0)$ & 0.108 & $(0.0462)^{* *}$ \\
KasenaNankana District(1/0) & 0.171 & $(0.0399) * * *$ \\
Bawku west District(1/0) & 0.171 & $(0.0386)^{* * *}$ \\
Age in years & 0.0116 & $(0.00696)^{*}$ \\
Age-squared & -0.000129 & $(7.32 \mathrm{e}-05)^{*}$ \\
Dependants in household & -0.00494 & $(0.00635)$ \\
Number of income generating activities & -0.0592 & $(0.0278)^{* *}$ \\
Initial savings & 0.000259 & $(8.70 \mathrm{e}-05) * * *$ \\
Non-formal Education & 0.128 & $(0.0663)^{*}$ \\
Primary School & -0.0102 & $(0.0345)$ \\
JSS/Middle & 0.0174 & $(0.0368)$ \\
SSS/Secondary & 0.0665 & $(0.0533)$ \\
Post Secondary & 0.0211 & $(0.117)$ \\
Days in a production cycle & 0.000719 & $(0.00028) * * *$ \\
Needs permission from spouse to borrow $(1 / 0)$ & -0.113 & $(0.0327) * * *$ \\
Male controls her business $(1 / 0)$ & -0.0687 & $(0.0285)^{* *}$ \\
Constant & 0.129 & $(0.153)$ \\
Observations & 246 & \\
\hline
\end{tabular}

Source: Akpalu, Alnaa and Aglobitse, (2011); *** $\mathrm{p}<0.01, * * \mathrm{p}<0.05, * \mathrm{p}<0.1$, standard errors are in parentheses

Box A shows that microfinance has a positive impact on technical efficiency in Box B. From Table 4, agro-processors who had received microfinance institutions loan(s) were found to be more efficient than their counterparts who did not receive microfinance institution loans. There is also a positive relationship between technical efficiency and the profits that the 
agro-processors make in Box $\mathbf{C}$.

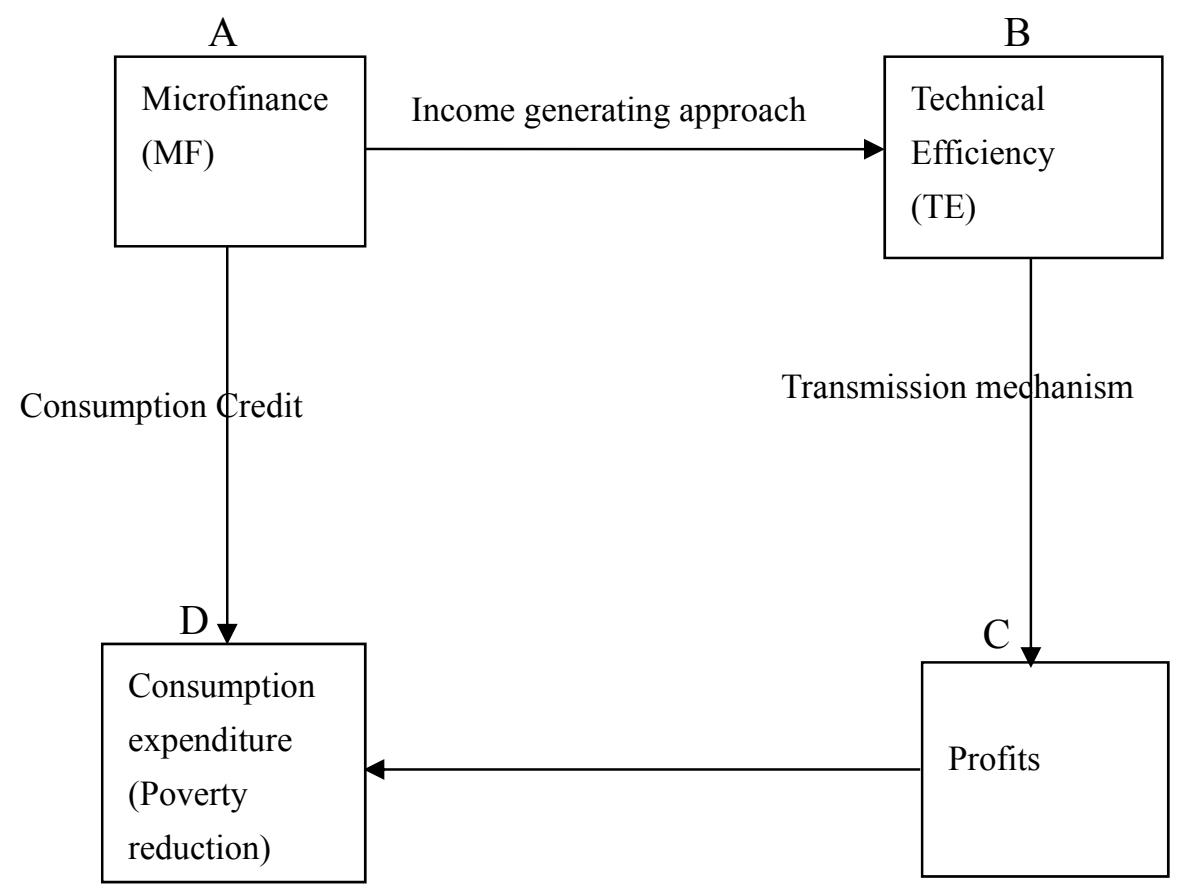

Figure 1: The linkages of microfinance, technical efficiency and Poverty reduction Source: authors' own construct

The spearman correlation coefficient of technical efficiency and Profits was found to be 0.2421 and significant at $1 \%$ level. Thus an increase in technical efficiency would also lead to an increase in profit level. In order to establish the direction of relationship between technical efficiency and profit, OLS estimation was carried out. In the estimation profit was interacted with access to microfinance thus determining the profits due only beneficiaries of microfinance institution loans. This was then regressed on technical efficiency and other variables. The results showed that 1 percent increase in technical efficiency would increase profits due only beneficiaries of microfinance institution loans by 82.5 percent per month. This implies that an increase in the technical efficiency of beneficiaries of microfinance institution loans will more than proportionately increase monthly profits of the beneficiaries.

Table 5 shows the OLS results with the log of profits of beneficiaries (the log of interaction between access to microfinance and amount of profit) of microfinance institution loans as the dependent variable. The results show that direct materials, labour and initial savings have positive impact on beneficiaries' profits while the number of income generating activities engaged in by respondents, has a negative impact on beneficiaries' profit. Since profit constitutes part of the income of the agro-processors, it is imperative that, improvement in the technical efficiencies of beneficiaries of microfinance should be the pre-occupation of all microfinance institutions. 


\section{Macrothink}

Table 5. Results of OLS estimation of the relationship between TE and Profits due beneficiaries of MF (dependent variable: profits)

\begin{tabular}{lll}
\hline Variables & Coefficients & Standard errors \\
\hline Technical efficiency & $0.825^{* *}$ & 0.410 \\
KasenaNankana District (1/0) & 0.267 & 0.236 \\
Bawku west District (1/0) & -0.173 & 0.227 \\
Age in years & 0.004 & 0.043 \\
Age-squared & 0.000 & 0.000 \\
Number of people in household & -0.042 & 0.036 \\
Dependants in household & 0.025 & 0.040 \\
Variable input & $0.07 * * *$ & 0.000 \\
Fixed input & 0.000 & 0.000 \\
Initial savings & $0.015^{* * *}$ & 0.001 \\
Value of Physical assets & 0.000 & 0.000 \\
No. of economic activities & $-0.700^{* * *}$ & 0.160 \\
Labour & $0.102^{*}$ & 0.057 \\
Constant & $3.884^{* * *}$ & 0.972 \\
Observations & 134.000 & \\
R-squared & 0.439 \\
\hline urce: Computed from field Survey data, (2011): $* * * p<0.01, * *$ & $0.05, * \mathrm{p}<0.1$
\end{tabular}

It was also found from Table 2 that an increase in the profits of the agro-processors has a positive impact on consumption expenditure on basic needs in Box D. Again, it was found that beneficiaries of microfinance institution loans spend more per week on basic needs than non-beneficiaries, implying that microfinance has a positive impact on consumption expenditure.

\section{Concluding Comments}

From the foregoing therefore, technical efficiency is a transmission mechanism through which MF can be used to increase household consumption expenditure. Therefore, an increase in technical efficiency will lead to an increase in household consumption expenditure. Thus, microfinance institutions which provide credit for income generating activities can actually have a positive impact on household consumption expenditure if the technical efficiencies of their beneficiaries are improved. This is so because efficient clients are able to repay their loans which help microfinance institutions to expand and reach out to more (poor) clients. Again in the context of the efficient clients it is an indication of breaking the poverty cycle if households are able to increase their consumption expenditure.

It is therefore recommended that microfinance institutions should endeavour to provide other training and advisory services (integrated approach) to their clients. These services will make the clients more efficient and better utilise the credit (loans) obtained and thus lead to poverty reduction. 


\section{References}

Akpalu, W., Alnaa, S. E., \& Aglobitse, P. B. (2012). Access to microfinance and intra household business decision making: Implication for efficiency of female owned enterprises in Ghana. Journal of Socio-Economics, 41(5), 513-518. http://dx.doi.org/10.1016/j.socec.2012.04.020

Annim, S. K. (2010). Microfinance Efficiency Trade-Offs and Complementarities. Brooks World Poverty Institute, University of Manchester. BWPI Working Pape 127, 907247-26-2.

Annim, S. K., \& Alnaa, S. E. (2013). Access to microfinance by rural women: Implications for poverty reduction in rural households in Ghana. Research in Applied Economics, 5(2), 19-41. http://dx.doi.org/10.5296/rae.v5i2.2974

Bhasin, K. V., \& Akpalu, W. (2001). Impact of micro-finance enterprises on the efficiency of micro-enterprises in Cape Coast. International Labour Organisation, IFLIP Research Paper 01-5.

Dunford, C. (2006). Evidence of Microfinance's contribution to achieving the millennium development goals, Freedom from Hunger, USA.

Dunn, E. (1996). Households, microenterprises, and debt, AIMS, Management Systems International 600 Water Street, S.W. Washington, D.C

Goyal K. S., \& Suhag S. K. (2003). Estimation of Technical Efficiency on wheat farms in Northern India - A panel data analysis. International Farm Management Congress.

Islam Z. M. K., Bäckman S., \& Sumelius J. (2011). Technical, Economic and Allocative Efficiency of Microfinance Borrowers and Non-Borrowers: Evidence from Peasant Farming in Bangladesh. European Journal of Social Sciences, 18(3).

Ledgerwood, J. (1999). Microfinance Handbook: An Institutional and Financial Perspective. World Bank, Sustainable Banking with the Poor Project. Washington, DC.

Littlefield E., Murduch J., \& Hashemi S. (2003). Is Microfinance an Effective Strategy to Reach the Millennium Development Goals? Retrieved from http://ifmr.ac.in/cmf/wp-content/uploads/2007/06/mf-mdgs-morduch.pdf

Marcus, R., Porter B., \& Harper C. (1999). Money Matters: Understanding Microfinance. Save the Children. London.

Marguerite, R. (2001). The Microfinance Revolution: Sustainable Finance for the Poor. World Bank: Washington.

Martínez-González, A. (2008). Technical efficiency of microfinance institutions: Evidence from Mexico Retrieved March 10, 2010, from http://etd.ohiolink.edu/view.cgi/MartinezGonzalez\%20Ariadna.pdf?osu1222266486

Nghiem S. H., Coelli, T., \& Rao, P. (n.d.). The Efficiency of microfinance in Vietnam: 
Evidence from NGO Schemes in the North and the Central Regions, Retrieved June 30, 2011, from http://hongson2.tripod.com/Efficiency_Microfinance.pdf

Richardson D. C. (2000). Unorthodox Microfinance: The Seven Doctrines of Success. Micro Banking Bulletin.

Tariq, M., \& Mohd-Izhar, A. (2010). Technical efficiency of microfinance institutions in India- a stochastic frontier approach. (Unpublished) Retrieved May 17, 2011 from http://mpra.ub.uni-muenchen.de/25454/1/MPRA_paper_25454.pdf

Seibel, H. D. (2005). Does history matter? The old and the new world of Microfinance in Europe and Asia. Paper presented at workshop on Southeast Asia's credit revolution in institutional, economic and cultural perspective, National University of Singapore.

Wodon, Q. T. (2000). World Bank Technical Paper No. 467.

Zeller M., Schrieder G., Von Braun J., \& Heidhues F. (1997). Rural Finance for Food Security for the Poor: Implications for Research and Policy. Washington, D.C., International Food Policy Research Institute.

\section{Copyright Disclaimer}

Copyright for this article is retained by the author(s), with first publication rights granted to the journal.

This is an open-access article distributed under the terms and conditions of the Creative Commons Attribution license (http://creativecommons.org/licenses/by/3.0/). 